\title{
WASPADA EPIDEMI HIV-AIDS DI INDONESIA
}

\author{
Handayani \\ Lab. Farmakologi, Fakultas Kedokteran, Universitas Nahdlatul Ulama Surabaya \\ Email: dr.handayani@unusa.ac.id
}

\begin{abstract}
One of the major health problem in Indonesia is the spreading of Acuquired Immune Deficiency Sidrome (AIDS) and Human Immuno Deficiency Virus(HIV). The development of HIV-AIDS in Indonesia is very alarming. The high number of people living with HIV-AIDS will affect on demography structure, health care systems, national economic and social order. Combating HIV-AIDS face a variety of complex challenges, requiring both a policy and action at the national, regional, and global. How to coverage prevention and treatment of HIV-AIDS, strengthening the quality of health services, assurance of drug availability, appropriate and effective regulation, elimination of stigma and discrimination, as well as tests and treatments for patients. Indonesian government have to involve various parties in HIV-AIDS, especially from the field of socio-cultural, educational, and religious for the prevention and improvement of patient care need to change people's behavior.
\end{abstract}

Keywords: HIV-AIDS, the impact of policy, prevention, social, cultural, religious

\section{PENDAHULUAN}

Acuquired Immune Deficiency Sidrome (AIDS) merupakan kumpulan gejala penyakit yang disebabkan oleh virus Human Immuno Deficiency Virus(HIV). Virus HIV mengakibatkan rusaknya sistem kekebalan tubuh manusia, mengakibatkan penderita kehilangan daya tahan tubuh, sehingga mudah terinfeksi dan meninggal karena berbagai penyakit infeksi, kanker dan lain-lain.Sampai saat ini belum ditemukan vaksin pencegahan ataupun obat yang dapat menyembuhkan penyakit ini secara tuntas. Jangka waktu antara terkena infeksi dan munculnya gejala penyakit pada orang dewasa memakan waktu rata-rata 5-7 tahun. Selama kurun waktu tersebut walaupun masih tampak sehat, secara sadar maupun tidak pengidap HIV dapat menularkan virusnya pada orang lain (Aleka, 2016).

Tingginya jumlah penderita HIV-AIDS akan berdampak terhadap struktur demografi, sistem pelayanan kesehatan, ekonomi nasional dan tatanan sosial. Tingginya angka kesakitan dan kematian pada usia produktif, akan mengakibatkan berkurangnya jumlah penduduk usia produktif, menurunya produktifitas kerja dan tingginya biaya perawatan akan memberatkan perekonomian nasional. Tingginya angka kesakitan pada penderita HIV-AIDS juga menambah beban pelayanan kesehatan, dapat menurunkan mutu pelayanan yang lainya. Tingginya angka kematian, selanjutnya meningkatkan jumlah anak- anak yang kehilangan orang tua, atau kurang mendapat asuhan yang baik sehingga meningkatkan kerawanan sosial (Abdul, 2014).

Penanggulangan HIV-AIDS di Indonesia menghadapi berbagai macam tantangan yang kompleks, sehingga membutuhkan kebijakan serta tindakan di tingkat daerah, nasional, regional, dan global. Program pencegahan dan pengobatan HIV; penguatan kualitas pelayanan kesehatan; kepastian ketersediaan obat; regulasi yang tepat dan efektif; penghapusan stigma dan diskriminasi; serta tes dan perawatan yang biayanya jangan sampai memberatkan masyarakat. Indonesia terus meningkatkan komitmen kami dalam penanggulangan AIDS (pidato Menteri Kesehatan, Prof. Dr. dr. Nila F. Moeleok, pada High Level Meeting of the General Assembly on HIV-AIDS (HLM) di Markas Besar PBB, New York pada tanggal 9 Juni 2016).

\section{EPIDEMIOLOGI}

Kasus HIV-AIDS pertama kali ditemukan pada tahun 1981, dan saat ini kasusnya sudah menyebar di berbagai negara di dunia dengan jumlah yang terus meningkat, menyerang pria, wanita serta anakanak. World Health Organisation (WHO) 
memperkirakan sekitar 10-12 juta orang dewasa dan anak-anak didunia telah terinfeksi dan setiap hari sebanyak 5000 orang tertular virus HIV. Menurut laporan dari WHO pada akhir tahun 2009, terdapat 33,3 juta orang hidup dengan HIV dan 1,8 juta orang meninggal karenanya. Laju penularan infeksi pada wanita jauh lebih cepat dari pada pria. Dari seluruh infeksi HIV $90 \%$ terjadi di negara berkembang terutama di Asia. Beberapa negara yang paling parah terkena antara lain : Thailand diperkirakan antara 500 ribu dan 800 ribu penduduknya telah terinfeksi, India sudah mencapai rata-rata antara 2-5 juta, di Bombay sudah 50\% pekerja seks dan 22,5\% perempuan hamil sudah terinfeksi virus HIV. Sementara itu negara-negara maju telah berhasil menekan laju infeksi HIV di negaranya. Tahun 2020 penanganan AIDS diseluruh dunia akan menghabiskan dana 514 milliar dollar AS. Setiap hari 7500 penduduk dunia terinfeksi HIV, lebih dari separo yang terinfeksi rata-rata berusia dibawah 25 tahun (Aleka, 2016).

\section{PERJALANAN PENYAKIT}

Masa inkubasi HIV berlangsung antara 5-7 tahun setelah infeksi. Selama masa inkubasi jumlah HIV dalam darah terus bertambah, sedangkan jumlah sel $\mathrm{T}$ semakin berkurang, sehingga kekebalan tubuh menurun. Masa inkubasi terdiri dari beberapa tahap, yaitu tahap jendela, tahap asimptomatik, dan tahap pembesaran kelenjar limfe. Tahap jendela (Window Period), terjadi setelah infeksi HIV, tenggang waktu 1-6 bulan, tes HIV negativ karena belum ada anti body HIV, tetapi penderita dapat menularkan HIV kepada orang lain. Tahap asimptomatik, antara 5-10 tahun, tidak ada gejala spesifik, tetapi bisa menularkan HIV pada orang lain. Tahap berikutnya terjadi pembesaran kelenjar limfe yang menetap dibanyak bagian tubuh. Selanjutnya terjadi penurunan sel $\mathrm{T}-4$ dibawah 200/microliter sehingga muncul berbagai macam penyakit, terutama penyakit-penyakit yang disebabkan infeksi oportunistik. Sebenarnya infeksi oportunistik ini juga sudah sering muncul sebelum seseorang mencapai masa AIDS, tetapi dia belum akan dikatakan dalam kondisi AIDS apabila sel T-4 didalam darahnya masih diatas 200/microliter (Dewi, 2013).

WHO telah membuat kriteria gejala sebagai pegangan dalam mendiagnosis AIDS, disebut gejala mayor dan gejala minor. Gejala minor atau ringan yaitu batuk kronis lebih dari satu bulan, bercakbercak merah dan gatal dipermukaan kulit pada beberapa bagian tubuh, Herpes Zorter yang muncul berulang-ulang, sariawan pada mulut dan tenggorokan yang disebabkan oleh jamur Candida albicans, dan pembengkakan kelenjar getah bening yang menetap di sekujur tubuh. Gejala-gejala mayor yaitu demam yang berkepanjangan lebih dari tiga bulan, diare kronis lebih dari satu bulan berulangulang maupun terus-menerus dan penurunan berat badan lebih 10 persen dalam kurun waktu tiga bulan.

\section{SITUASI HIV-AIDS DI INDONESIA}

Kasus penularan AIDS pertama di Indonesia dilaporkan terjadi pada tahun 1987, kemudian disusul dengan kasus-kasus berikutnya, sehingga pada tanggal 31 januari 1995 tercatat pengidap HIV 211 orang dan 69 penderita AIDS, 44 orang diantaranya meninggal. Data terakhir bulan Juni 1999 tercatat 88 mengidap HIV dan 26 penderita AIDS (sampai dengan 31 Agustus 1999). Serupa dengan pola penyebaran dinegara lain, di Indonesiapun penyebaran HIV-AIDS pada awalnya terjadi diantara orang-orang homo seks, kemudian muncul pada sekelompok kecil orang-orang yang berperilaku resiko tinggi seperti pecandu obat narkotika dan para tuna susila. Namun pada perkembanganya saat ini HIV-AIDS juga banyak dialami ibu rumah tangga dan juga anak-anak (Kementrian RI, 2016).

Perkembangan HIV dan AIDS di Indonesia semakin memprihatinkan. Indonesia kini dikategorikan sebagai negara dengan tingkat endemi HIV-AIDS terkonsentrasi. Data Badan Koordinasi Keluarga Berencana Nasional (BKKBN) menyebutkan kondisi HIV-AIDS di dunia turun dari 40,3 juta pada tahun 2005 menjadi tinggal 33,2 juta pada 2007. Berdasarkan laporan dari tahun ke tahun, kasus AIDS di Indonesia menunjukkan tren peningkatan yang terus-menerus. Berdasarkan laporan Ditjen Pencegahan Penyakit dan Penyehatan Lingkungan (P2PL) Kemenkes RI juga dapat dilihat jumlah kumulatif kasus AIDS di

Indonesia sampai dengan akhir Juni 2011 sebanyak 26.483 kasus (Stratnas Penanggulangan HIV-AIDS, 2011, Ditjen PP \& PL, 2014). 


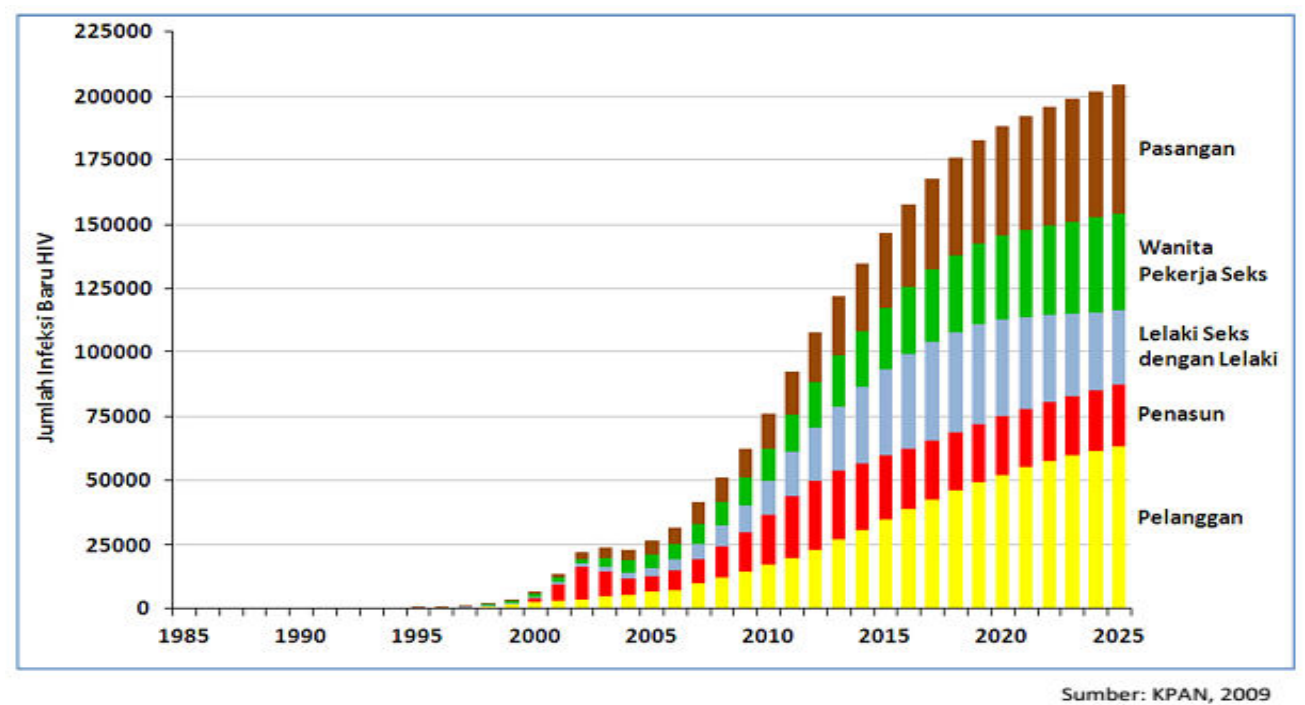

Gambar 1. Kecenderungan epidemi HIV di Indonesia

Kecenderungan peningkatan kasus HIV-AIDS di Indonesia dari tahun ke tahun, serta cara penularanya

Beberapa penyebab dari tertularnya seseorang oleh HIV-AIDS antara lain:

1. Mereka yang mempunyai banyak pasangan seksual, baik homo maupun hetero.

2. Penerima transfuse darah.

3. Bayi yang dilahirkan dari ibu yang positif HIV.

4. Pecandu narkotika secara suntikan.

5. Pasangan dari pengidap AIDS atau yang positif HIV.

6. Prilaku seks beresiko tinggi dan makin maraknya industry seks.

7. Kurangnya informasi tentang penularan HIV/AIDS dan masalah budaya

Faktor lain yang menyebabkan terus meningkatnya kasus AIDS di Indonesia adalah masih kurangnya informasi tentang penularan HIVAIDS dan dan masalah budaya. Kultur kita masih belum terbuka untuk membicarakan masalah yang sensitif. Seks masih dianggap tabu untuk dibicarakan. Akhir akhir ini banyak ibu rumah tangga yang "baik-baik" tertular virus HIV-AIDS dari suaminya yang sering melakukan hubungan seksual selain dengan istrinya. Hal ini disebabkan oleh budaya permisif, sehingga perempuan tidak berdaya serta tidak mempunyai bargaining position (posisi rebut tawar) terhadap suaminya. Kaum perempuan tidak memiliki pengetahuan akan bahaya yang mengancamnya (Herlin, 2014).

\section{DAMPAK}

\section{Dampak Demografi}

Efek jangka panjang endemi HIV-AIDS yang meluas seperti yang telah terjadi di Papua adalah dampaknya demografi. Karena tingginya proporsi kelompok umur yang lebih muda terkena penyakit yang membahayakan ini, dapat diperkirakan nantinya akan menurunkan angka harapan hidup. Hal ini menjadi masalah yang penting karena hilangnya individu yang terlatih dalam jumlah besar tidak akan mudah dapat digantikan. Biaya karena kehilangan seperti itu seperti meningkatnya pekerja yang tidak hadir, meningkatnya biaya pelatihan, pendapatan yang berkurang, dan sumber daya yang seharusnya dipakai untuk aktivitas produktif terpaksa dialihkan pada perawatan kesehatan, waktu yang terbuang untuk merawat anggota keluarga yang sakit, dan lainnya,juga akan meningkat.

\section{Dampak Terhadap Sistem Pelayanan Kesehatan}

Tingginya tingkat penyebaran HIV-AIDS berarti bahwa semakin banyak orang sakit, dan membutuhkan jasa pelayanan kesehatan. Biaya langsung dari perawatan kesehatan tersebut semakin lama akan menjadi semakin besar. Banyak waktu yang dihabiskan oleh anggota keluarga untuk merawat pasien, dan tidak dapat melakukan aktivitas yang produktif. Waktu dan sumber daya 
yang diberikan untuk merawat pasien HIV-AIDS dapat mempengaruhi program lainnya dan menghabiskan sumber daya untuk aktivitas kesehatan lainnya.

\section{Dampak Terhadap Ekonomi Nasional}

Mengingat bahwa HIV lebih banyak menjangkiti orang muda dan mereka yang berada pada umur produktif utama (94\% pada kelompok usia 19 sampai 49 tahun), epidemi HIV-AIDS memiliki dampak yang besar pada angkatan kerja, akan meningkatkan terjadinya kemiskinan dan ketidakseimbangan ekonomi. Dari sudut pandang individu HIV-AIDS berarti tidak dapat masuk kerja, jumlah hari kerja yang berkurang, kesempatan yang terbatas untuk mendapatkan pekerjaan dengan gaji yang lebih baik dan umur masa produktif yang lebih pendek. Dampak individu ini selanjutnya menjadi dampak ekonomi pada keluarga dan komunitas.

Dampak pada dunia bisnis hilangnya keuntungan dan produktivitas yang diakibatkan oleh berkurangnya semangat kerja, meningkatnya ketidakhadiran karena izin sakit atau merawat anggota keluarga, percepatan masa penggantian pekerja karena kehilangan pekerja yang berpengalaman lebih cepat dari yang seharusnya. HIV-AIDS juga berperan dalam berkurangnya moral pekerja (takut akan diskriminasi, kehilangan rekan kerja, rasa khawatir) dan juga pada penghasilan pekerja akibat meningkatnya biaya perawatan medis dari pusat pelayanan kesehatan para pekerja, pensiun dini, pembayaran dini dari dana pensiun akibat kematian dini, dan meningkatnya biaya asuransi.

\section{Dampak Terhadap Tatanan Sosial}

Adanya stigma dan diskriminasi akan berdampak pada tatanan sosial masyarakat. Penderita HIV-AIDS dapat kehilangan kasih sayang dan kehangatan pergaulan sosial. Sebagian akan kehilangan pekerjaan dan sumber penghasilan yang pada akhirnya menimbulkan kerawanan sosial. Sebagaian mengalami keretakan rumah tangga sampai perceraian. Jumlah anak yatim dan piatu akan bertambah yang akan menimbulkan masalah tersendiri. Oleh sebab itu keterbukaan dan hilangnya stigma dan diskriminasi sangat perlu mendapat perhatian dimasa mendatang
Penderita HIV-AIDS yang tidak dapat melaksanakan fungsinya untuk mencari nafkah, membesarkan anak, memberikan pendidikan terhadap anak dan lain-lain. Demikian juga untuk masa yang akan datang dampak ini akan terasa pada generasai berikutnya yakni terjadinya kemiskinan yang lebih berat bagi keluarga maupun bagi negara. Anak-anak dari orang tua yang terinfeksi HIV sebagian besar akan menjadi yatim piatu, kehilangan pendidikan dan sebagainya, sehingga meningkatkan kerawanan sosial (Abdul, 2014).

\section{STRATEGI NASIONAL PENANGGULANGAN HIV-AIDS}

Sasaran umum pembangunan jangka panjang kedua (PJP-II) sebagaimana dinyatakan dalam GBHN 1993 adalah terciptanya kwalitas manusia dan kwalitas masyarakat Indonesia yang maju dan mandiri. Penyebaran HIV-AIDS dalam masyarakat bukan semata-mata hanya masalah kesehatan saja, tetapi mempunyai implikasi politik, ekonomi, sosial, etis, agama dan hukum, bahkan dampaknya secara nyata cepat atau lambat menyentuh semua aspek kehidupan bangsa dan negara. Hal ini mengancam upaya bangsa untuk meningkatkan kwalitas sumber daya manusia. Dalam rangka mengamankan jalannya pembangunan nasional, demi terciptanya kwalitas manusia yang diharapkan, perlu peningkatan upaya penaggulangan HIV-AIDS, yang melibatkan semua sektor pembangunan nasional melalui program yang terarah, terpadu dan menyeluruh. Untuk itu disusunlah strstegi nasional penanggulangan HIVAIDS yang komprehensif, menyeluruh dan multi sektor, guna mewujudkan satu gerak langkah dalam penaggulangan AIDS tersebut dan yang berdasarkan Keputusan Presiden NO. 36 tahun 1994 tentang komisi penanggulangan AIDS (Ditjen PP\&PL, 2014).

Strategi Nasional penanggulangan HIV-AIDS di Indonesia merupakan kerangka acuan dan panduan untuk setiap upaya, baik oleh pemerintah, masyarakat LSM, keluarga, perorangan, universitas dan lembaga-lembaga penelitian, donor dan badanbadan internasional agar dapat bekerja sama dalam 
kemitraan yang efektif dan saling melengkapi dalam lingkup keahlian dan kepedulian masingmasing berdasarkan Pasal 5 Keputusan Presiden nomor 36 Tahun 1994. Strategi Nasional ini disusun dengan sistematika: prinsip-prinsip dasar penanggulangan HIV-AIDS, lingkup program, peran dan tanggung jawab, kerjasama internasional dan pendanaan (Ditjen PP\&PL, 2014).

\section{Peta Epidemi HIV di Indonesia}

Estimasi jumlah ODHA 2009: 186.257 orang

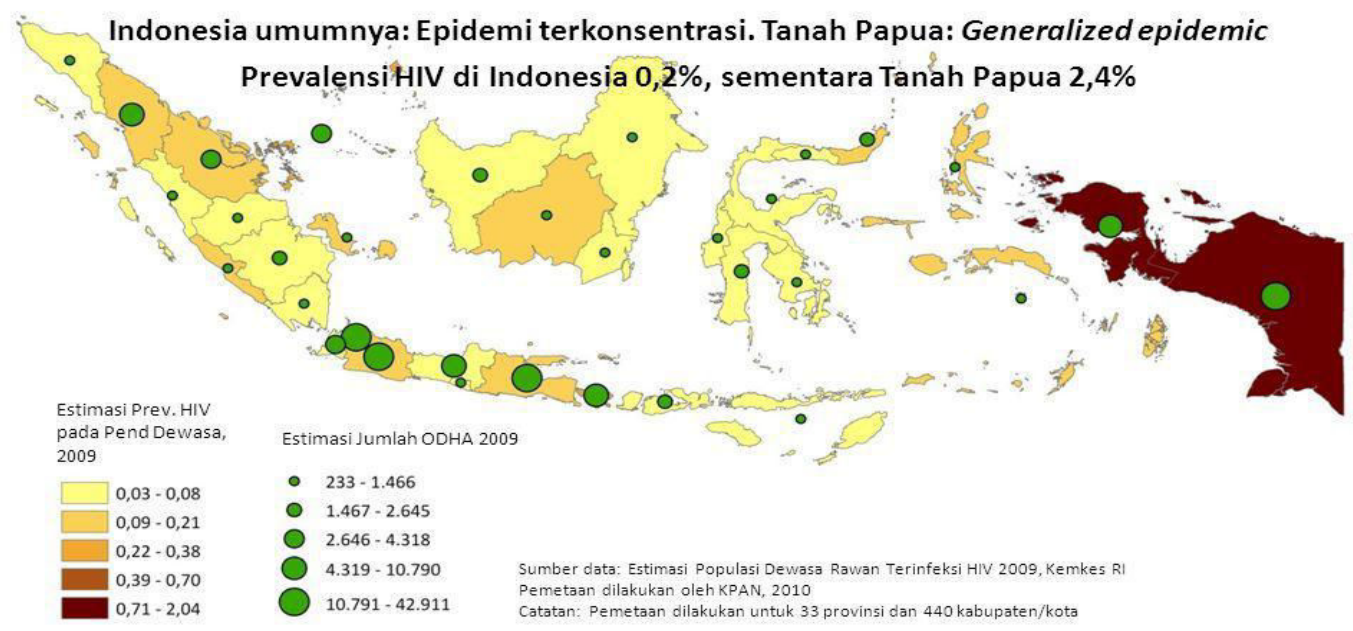

Gambar 2. Peta Epidemi HIV di Indonesia

HIV-AIDS di Indonesia ditangani oleh Komisi Penanggulangan AIDS (KPA) Nasional dan Badan Koordinasi Keluarga Berencana Nasional (BKKBN) dan memiliki Strategi Penanggulangan AIDS Nasional untuk wilayah Indonesia. Ada 79 daerah prioritas di mana epidemi AIDS sedang meluas, dengan delapan provinsi prioritas yaitu : Papua, Papua Barat, Sumatera Utara, Jawa Timur, Jakarta, Kepulauan Riau, Jawa Barat, dan Jawa Tengah. Kegiatan penanggulangan meliputi pencegahan, pelayanan, pemantauan, pengedalian dan penyuluhan dll.

Beberapa prinsip dalam penanggulangan HIVAIDS yaitu (Lutfi, 2013, Dewi, 2014): a. Upaya penanggulangan HIV-AIDS dilaksanakan bersama oleh masyarakat dan pemerintah.

b. Setiap upaya penanggulangan harus mencerminkan nilai-nilai agama dan budaya yang ada di Indonesia.

c. Setiap kegiatan diarahkan untuk mempertahankan dan memperkukuh ketahanan dan kesejahteraan keluarga, serta sistem dukungan sosial yang mengakar dalam masyarakat.

d. Pencegahan HIV-AIDS diarahkan pada upaya pendidikan dan penyuluhan untuk memantapkan perilaku yang baik dan mengubah perilaku yang berisiko tinggi. 


\section{PROVINSI DI INDONESIA DENGAN KUMULATIF KASUS HIV \& AIDS TERBANYAK S/D 30 SEPT 2014}

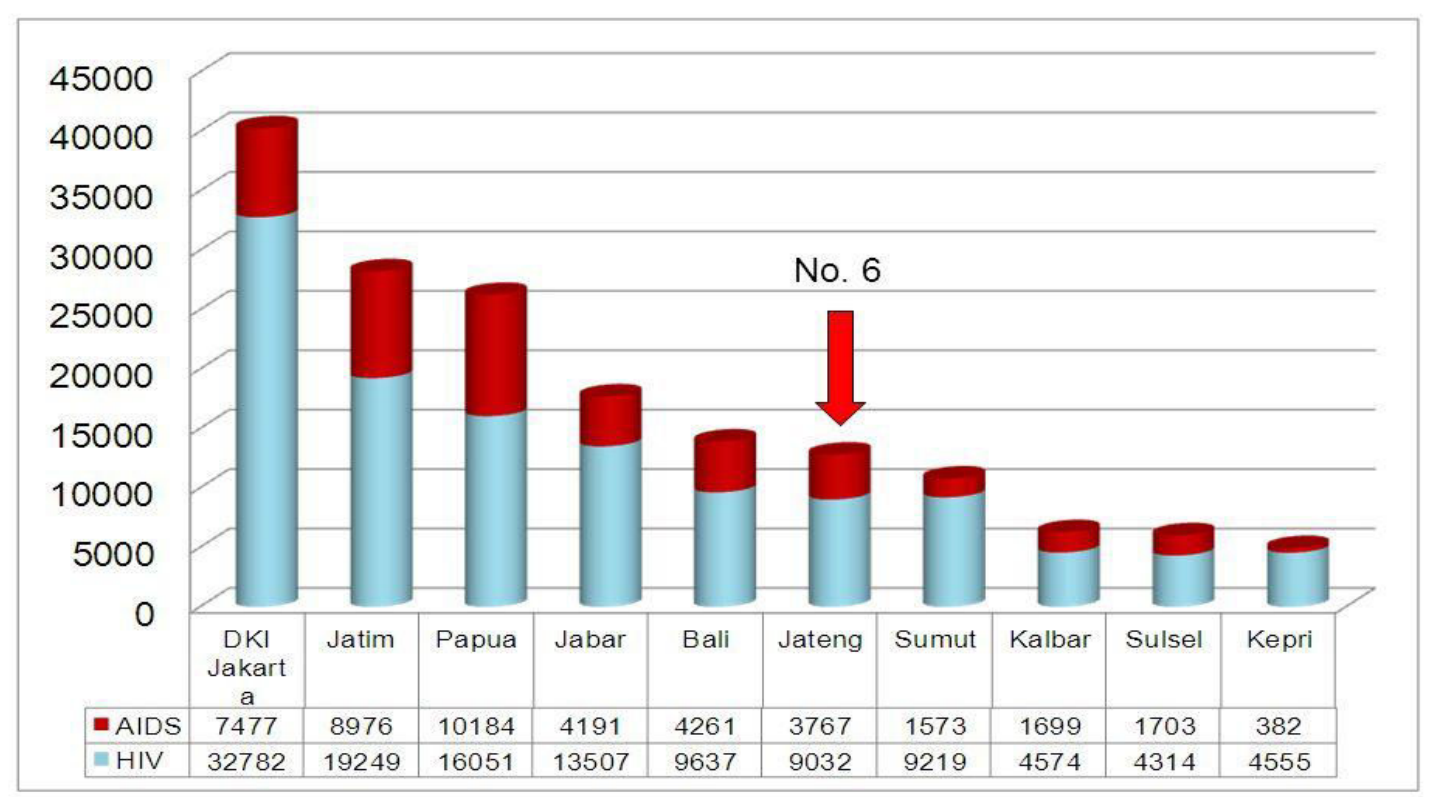

Gambar 3. 10 Provinsi dengan jumlah penderita HIV-AIDS terbanyak di Indonesia

e. Setiap orang berhak untuk mendapat informasi yang benar untuk melindungi diri dan orang lain terhadap infeksi HIV.

f. Setiap kebijakan, program, pelayanan dan kegiatan harus tetap menghormati harkat dan martabat dari para pengidap HIV, penderita AIDS dan keluarganya.

g. Setiap pemeriksaan untuk mendiagnosa HIVAIDS harus didahului dengan penjelasan yang benar dan mendapat persetujuan yang bersangkutan (informed consent), sebelum dan sesudahnya harus diberikan konseling yang memadai dan hasil pemeriksaan wajib dirahasiakan.

h. Diusahakan agar peraturan perundangundangan mendukung dan selaras dengan Strategi Nasional Penanggulangan HIV-AIDS di semua tingkat.

i. Setiap pemberi pelayanan kepada pengidap HIV, penderita AIDS berkewajiban memberikan pelayanan tanpa diskriminasi.
Tujuan program penanggulangan HIV-AIDS yaitu: mencegah penularan virus HIV, mengurangi sebanyak mungkin penderitaan perorangan, serta dampak sosial dan ekonomis dari HIV-AIDS di seluruh Indonesia, menghimpun dan menyatukan upaya-upaya nasional untuk penanggulangan HIVAIDS.

Sasaran program yaitu kelompok resiko tinggi (Wanita Tuna Susila /WTS, karyawati panti pijat, night club, bar dan diskotik, waria dan gay, narapidana, penderita penyakit menular seksual), dan kelompok resiko rendah (penerima donor darah, ibu hamil, calon Tenaga Kerja Indonesia/TKI, pelajar/mahasiswa, karyawan).

Kebijakan strategis nasional dalam penanggulangan HIV-AIDS di Indonesia adalah sebagai berikut (Ditjen PP \& PL, 2014; Abdul, 2014): 
a. Pemerintah pusat bertugas melakukan regulasi dan standarisasi secara nasional kegiatan program AIDS dan pelayanan bagi orang dengan HIV-AIDS (ODHA)

b. Penyelenggaraan dan pelaksanaan program dilakukan sesuai azas desentralisasi dengan Kabupaten/kota sebagai titik berat manajemen program;

c. Pemerintah berkewajiban menjamin tersedianya obat antiretrovirus (ARV) maupun reagen pemeriksaan secara berkesinambungan;

d. Pengembangan layanan bagi ODHA dilakukan melalui pengkajian menyeluruh dari berbagai aspek yang meliputi: situasi epidemi daerah, beban masalah dan kemampuan, komitmen, strategi dan perencanaan, kesinambungan, fasilitas, petugas kesehatan dan pembiayaan. Sesuai dengan kewenangannya pengembangan layanan ditentukan oleh Dinas Kesehatan.

e. Setiap pemeriksaan untuk mendiagnosa HIVAIDS harus didahului dengan penjelasan yang benar dan mendapat persetujuan yang bersangkutan (informed consent). Konseling yang memadai harus diberikan sebelum dan sesudah pemeriksaan, dan hasil pemeriksaan diberitahukan kepada yang bersangkutan tetapi wajib dirahasiakan kepada pihak lain;

f. Setiap pemberi pelayanan berkewajiban memberikan layanan tanpa diskriminasi kepada ODHA. Layanan bagi ODHA dilakukan secara holistik, komprehensif dan integratif sesuai dengan konsep layanan perawatan yang berkesinambungan.

g. Keberpihakan kepada ODHA dan masyarakat (patient and community centered); Upaya mengurangi infeksi HIV pada pengguna napza suntik melalui kegiatan pengurangan dampak buruk (harm reduction) dilaksanakan secara komprehensif dengan juga mengupayakan penyembuhan dari ketergantungan napza;

h. Penguatan dan pengembangan program diprioritaskan bagi peningkatan mutu pelayanan, dan kemudahan akses terhadap pencegahan, pelayanan dan pengobatan bagi ODHA.

i. Pengembangan layanan dilakukan secara bertahap pada seluruh pelayanan yang ada sesuai dengan fungsi dan strata pelayanan dengan mempertimbangkan kemampuan dan kesiapan sarana, tenaga dan dana. j. Pencapaian target program nasional juga memperhatikan komitmen dan target internasional.

\section{KESIMPULAN}

Dari data dan informasi yang telah dijabarkan diatas, dapat disimpulkan bahwa

1. Penyakit HIV-AIDS merupakan penyakit menular, berbahaya, dan belum ada obatnya,dengan angka kematian tinggi.

2. Indonesia termasuk negara dengan penularan HIV-AIDS yang tinggi.

3. Tingginya jumlah penderita HIV-AIDS berdampak terhadap demografi, sistem pelayanan kesehatan, ekonomi nasional dan tatanan sosial di Indonesia.

4. Pemerintah telah menyusun strategi dan program penanggulangan penyebaran HIVAIDS.

5. Penaggulangan HIV-AIDS di Indonesia memerlukan kerjasama berbagai pihak, program yang terarah, terpadu dan menyeluruh, baik dari pemerintah, swasta, politikus, tokohtokoh masyarakat, LSM bidang sosial budaya dan agama untuk merubah perilaku masyarakat Indonesia dalam penanggulangan HIV-AIDS.

\section{DAFTAR PUSTAKA}

Abdul Najib, 2014. Pola Kebijakan Penanggulangan Penularan HIV. Diakses dari http://gemanwyogyakarta.blogspot.com/201 4/11/struktur-kami.html, 17 Januari 2016.

Aleka Zulfikar, 2016. Strategi Penanggulangan HIV/AIDSEmail, Dinas Kesehatan Prov. Bengkulu, Seksi Penelitian dan Informasi Kesehatan, email alekazulfikar73@mail.com._Diakses http://dinkes.bengkuluprov.go.id/ver1/index. php/127-strategi-penanggulangan-hivaidsdari tgl : 15 Des 2016.

Dewipusphasary, 2014. Kecenderungan Epidemi HIV. Diakses dari http://.blogspot.co.id/2014/10/kecenderunga n-epidemi-hiv.html, 16 Desember 2016. 
Ditjen PP \& PL Kemenkes RI, 2014. Statistik

Kasus HIV/AIDS di Indonesia.

http://www.spiritia.or.id/Stats/StatCurr.php?1

ang=id\&gg $=1$

Herlin Nuraeni Wijaya, 2014. Laporan

perkembangan hiv/aids berdasarkan jenis

kelamin di indonesia tahun 2014, Sukabumi

Health Science

Collage.http://herlinnuraeniwijaya.blogspot.c o.id/2014/10/laporan-perkembangan-

hivaids_13.html
Kementerian Kesehatan RI dan Perwakilan Tetap RI untuk PBB, 2016.Indonesia Tingkatkan Komitmen Penanggulangan HIV-AIDS Siaran Pers Bersama di New York, New York, 9 Juni 2016. Diakses dari http://www.depkes.go.id/article/view/160610 00001/indonesia-tingkatkan-komitmenpenanggulangan-hiv-aids.html

Lutfi Nurdiansyah, 2013. Kondisi HIV \& AIDS Di Jawa Tengah 1993 S/D 31 Des 2013.Diakses dari http://slideplayer.info/slide/3957089/, 15 Desember 2016. 